\title{
International workshop on safety assessment of consumer goods coming from recovered ma- terials in a global scale perspective
}

\author{
Hội thảo quốc tế về đánh giá tính an toàn của hàng hóa tiêu dùng tù vật liệu tái \\ chế trong viến cảnh toàn cầu \\ Event report
}

Bilitewski, Bernd ${ }^{1}$; Barceló, Damià ${ }^{2}$; Darbra, Rosa Mari³ ; v.d. Voet, Ester ${ }^{4}$; Belhaj, Mohammed ${ }^{5}$; Benfenati, Emilio ${ }^{6}$; Ginebreda, Antoni ${ }^{2}$; Grundmann, Veit ${ }^{1}$

${ }^{I}$ Institute of Waste Management and Contaminated Site Treatment, Technische Universität Dresden. Pratzchwitzer Str. 15. D-01796 Pirna, Germany; ${ }^{2}$ Department of Environmental Chemistry, IIQAB-CSIC, Jordi Girona, 18-26. 08034 Barcelona, Spain; ${ }^{3}$ Universitat Politècnica de Catalunya. ETSEIB. Diagonal, 647. 08028 Barcelona, Spain; ${ }^{4}$ University of Leiden. CML. Einsteinweg, 2. P.O. Box 9518. 2300 RA Leiden, Netherlands; ${ }^{5}$ Swedish Environmental Research Institute. P.O. Box. 5302. Aschebergatan 44. S-400 14 Gothenburg, Sweden; ${ }^{6}$ Istituto di Ricerche Farmacologiche Mario Negri. Via La Masa, 19. 20156 Milano, Italy

\begin{abstract}
Chemicals and additives in products being produced and marketed globally, this makes an international harmonised assessment and management essential. Chemical testing, research on risks, impacts and management options are carried out throughout the globe but quite fractionated to certain areas and sectors and much too often with little linkages between the different scientific communities. The coordination action (CA) "RISKCYCLE" is aimed to establish and co-ordinate a global network of European and international experts and stakeholders to define together future needs of $\mathrm{R}+\mathrm{D}$ contributions for innovations in the risk-based management of chemicals and products in a circular economy of global scale leading to alternative strategies to animal tests and reduced health hazards. The partners joining this action seek to explore the synergies of the research carried out within different programmes and countries of the EU, in Asia and overseas to facilitate the intensified communication with researchers, institutions and industries about the risks of hazardous chemicals and additives in products and risk reduction measures and to improve the dispersion of available information. The RISKCYCLE network will closely collaborate with related projects, EU and international bodies and authorities such as for example the Organisation for Economic Co-operation and Development (OECD), the European Chemical Industry Council (CEFIC) and the Scientific Committee on Health and Environmental Risks in Europe.
\end{abstract}

Mục đích chính của RISKCYCLE là xác đinh các nghiện cúu và sụ phát triển trong tuoong lai cấn thiết để thành lập một phuơng pháp đánh giá dựa trện rủi ro cho các hoá chất và các sản phấm. Phuơng pháp này sẽ giúp giảm bớt các thủ nghiệm trện động vật, đổng thờ đảm bảo sư phát triển các hóa chất mới và một mô hình quản lý sản phấm để giảm thiểu rủi ro đối với sức khởe và môi truờng. để đạt được mục tiệu này, trước hết cấn thu thập và đánh giá thông tin hiện có về các hoá chất và đặc biệt là các chất phu gia được sủ dụng trong sản phấm công nghiệp và tiệu dùng. Nhiều hợp chất độc hại tiềm tàng được giao dich mua bán trện toàn thế giới nhu là chất phu gia trong các sản phấm khác nhau. RISKCYCLE sẽ tập trung vào tác động và hậu quả của các chất phu gia trong sáu lĩnh vục: dệt may, điện tủ, nhựa, da, giấy và dấu mó bôi trơn. Trong ngành công nghiệp dệt may việc sủ dụng các chất phu gia sẽ được nghiện cúu, trong khi ở ngành điện tủ và công nghiệp dệt may, việc sủ dụng các chất chống cháy, đặc biệt là chất chống cháy chứa brôm nhu PBDEs và $H B C D$, sẽ đước phân tích. Trong công nghiệp da, kim loại năng nhu crom sẽ đươc quan tâm. Việc sủ dụng chất diệt côn trùng trong ngành công nghiệp giá́y cũng sẽ là một mối quan tâm chính của các hoạt động phối hợp.

Keywords: risk-based management; additives; recycling; impact assessment; risk assessment 


\section{Workshop organization, objective and topics}

The workshop on "Safety assessment of consumer goods coming from recovered materials in a global scale perspective" is the first of the Thematic Workshops organized within the framework of the European Union (EU)funded Coordination Action "Risk-based management of chemicals and products in a circular economy at a global scale', (RISKCYCLE).

The global trade of chemicals and products containing chemical additives such as paint, cosmetics, household cleaners, paper and cardboard, plastic toys, textiles, electronic appliances, petrol, lubricants etc. has resulted in a substantial release of harmful substances to the environment with risk to human and nature on a worldwide scale.

The overall objective of RISKCYCLE aims to establish a global network to explore the synergies of the research carried out within different programmes and countries of the EU, USA, Japan, China, India, Brazil, Vietnam etc. and to facilitate the communication with researchers, institutions and industries and make the information about the risks of hazardous chemicals and additives in products and the risk reduction measures for substances widely available. It is necessary to establish and co-ordinate a global network of European and international experts and stakeholders from different programmes to define together future needs of $\mathrm{R}+\mathrm{D}$ contributions for innovations in the field of risk-based management of chemicals and products of a circular economy in a global perspective making use of alternative strategies to animals test if possible and necessary.

The first RISKCYCLE workshop was held from 4 to 5 May 2010 in Hanoi, Vietnam. The workshop was coordinated by Technische Universität Dresden (TUD) and hosted by Hanoi University of Science (HUS). This first workshop served to present and summarise the results and achievements of the first period of the RISKCYCLE project and also as a platform for exchanging information and involved scientists, policy-makers and stakeholders related to chemicals and risk assessment. The local scientists and policy-makers also received the opportunity to present particular local problems related to the main tasks of RISKCYCLE.

Due to the long-standing relationship between HUS and TUD, the Vietnamese university was chosen to be the host of the first workshop. Nearly 70 invitations were sent to interested persons, from which a majority took part at the workshop. More than 25 experts gave presentations on different topics related to waste management, chemical additives, recycling of products, risk assessment and toxicology. The results and perceptions of the first workshop were very useful for the project development as well as for the organization of the following project workshops.

\subsection{Workshop introduction}

The first session of the workshop was dedicated to welcome all participants to Hanoi University of Science and to introduce the goal and scope of the project. The rector of HUS, Prof. Bui Duy Cam, welcomed all guests and participants and highlighted the long-standing education and research relationship between Vietnam and Germany, especially between HUS and TUD. Further on, he wished all the participants a very successful workshop.

The coordinator of the project, Prof. Dr. Bernd Bilitewski, introduced the goal and scope of the project RISKCYCLE to all workshop attendees and highlighted the necessity of a successful workshop and the importance of a global network of information about the risk of chemicals and additives in products. In addition, he introduced the philosophy of a coordinated action, the difference to a research project and the objectives of the project.

As guest speaker, Ms. Hannelore Bossmann, Head of the German Academic Exchange Service (DAAD), regional division Southeast Asia, highlighted the long-standing Vietnamese-German exchange relationship and introduced several supporting programs for Vietnamese and German students and lecturers. In 2004, the Master's Course "Waste Management and Contaminated Site Treatment" was established between HUS and TUD. The course's curriculum and the DAAD financial support gave the students the opportunity to exchange knowledge between the Vietnamese and German universities and allowed them to benefit from experiences of an education system abroad.

\subsection{Waste management problems in Vietnam}

The session was dedicated to waste management problems in Vietnam and included also information about the European Chemicals Regulation 'REACH'. The session included three presentations, covering both general aspects and specific case studies.

The first presentation entitled 'Problems in waste management on the way of sustainable development' was mainly about the generation of electronic and electric waste (WEEE) in Vietnam. In 2004, household share in Vietnam was estimated to 20 million tonnes and industry share was about 3.5 million tonnes. Dumping is the most used practice to handle WEEE in Vietnam whereas impacts on health and the environment are considerable. In his presentation, Mr. Nguyen Thanh Yen (MSc.) highlighted the fact that the law related to WEEE is often violated. Taking care of waste is done in an incompetent way and the existing incinerators do not meet the required standards while the financial resources for new incinerators are very scarce. The institutions are also blamed for not being efficient to regulate WEEE.

Prof. Dr. Uwe Lahl, who was deeply involved in the compilation of the REACH document, gave the second presentation on 'The European new chemicals legislation $\mathrm{REACH}$ and its interrelation to the waste sector'. Prof. Lahl highlighted several aspects to be considered by policy makers as well as researchers in the sake of mitigating the effects of chemicals on human health and environment. 
Prof. Pham Hung Viet offered the third interesting presentation with the title 'Review on hazardous persistent pollutants available in all products in Vietnam and other countries'. The content of the lecture was about chemicals emerging in South-East Asia and in Vietnam (Hung and Thiemann, 2002; Minh et al., 2006). One of the causes of this emergence is assumed to be innovation in the agricultural sector where chemicals are intensively used to increase yield. The impact of intensive use of chemicals in this sector has led to increased emissions of chemicals to the environment whereas the impacts are considerable. To take care of WEEE in Vietnam, Mr. Pham Hung Viet informed about different collaboration with other countries i.e. South Korea.

\subsection{Additives used in the paper and leather sectors}

The session was dedicated to additives employed by two industrial sectors, namely paper and leather. The session included five presentations that covered both general aspects and specific case studies.

Mr. Nguyen Hoang Duc, from the Pollution Control Department Vietnam Environment Administration (VEA) of the Ministry of Natural Resources and Environment (MONRE) presented a general overview of the current situation of waste recovery and recycling in Vietnam.

Dr. Antoni Ginebreda introduced the basic philosophy and criteria for the design of a database of chemical additives of general purpose, based on a web platform service. A direct example of a pilot database was also shown in the internet.

In second place, an overview of the paper and leather sectors was exposed, and bisphenol A and nonyphenol were selected as relevant additives. Prof. Dr. Samuel Schabel from the Institute for Paper Science and Technology, Darmstadt, argued on the relevance of the former since this compound is only used in certain types of paper. Conversely, biocides were suggested as more significant compounds, from a risk assessment point of view.

Prof. Nguyen Thi Dien Trang presented as an interesting case study on paper recycling in handicraft villages in Vietnam (Vietpaper, 2007; see also Figure 1 and 2). Prof. Trang highlighted the pros and cons of such activity: while the most positive aspect was the high efficiency achieved in the process, the main concern laid on the heavy environmental impact caused by this activity.

Prof. Dr. Damià Barceló's presentation focused on nonylphenol as an example of global pollutant extensively used in the textile, paper and leather sectors in form of polyethoxylated derivatives as non-ionic detergents. The profile presented covered its most relevant features on many aspects such as production, uses, mass flows, emissions to the environment, environmental occurrence, fate and degradation, health concerns, regulatory aspects and abatement measures.

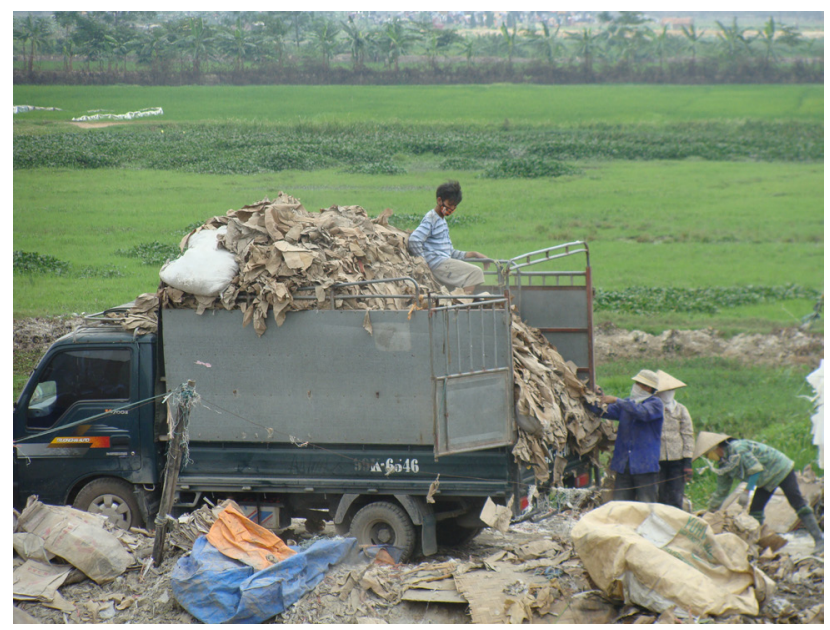

Figure 1. Recollection of paper in Vietnam to be recycled in villages

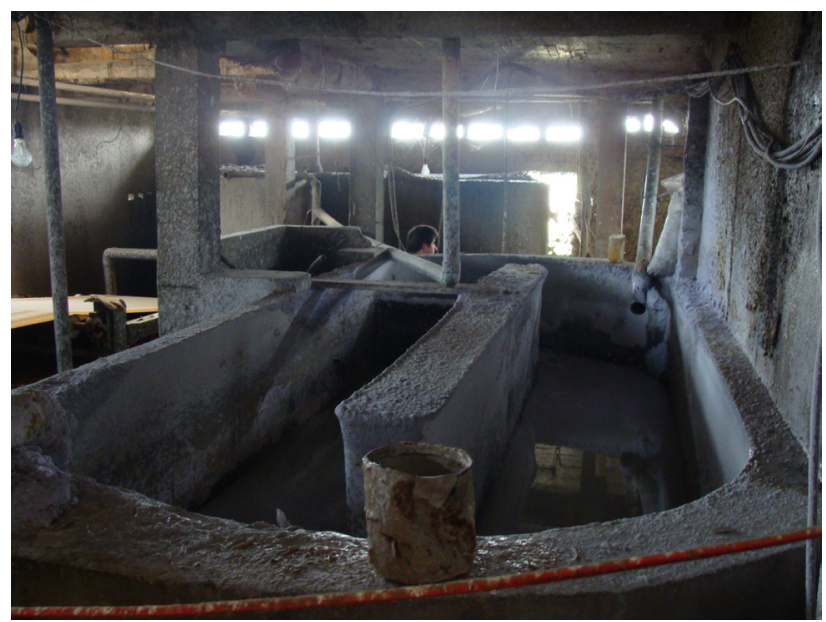

Figure 2. Paper treatment process to obtain final recycled paper

The last presentation was given by Dr. Henrik F. Larsen who exposed a case study on the production of printed paper from the point of view of Life Cycle Assessment (LCA) (Larsen et al., 2009). Interestingly, the speaker differentiated the impacts caused by the paper production itself from the printing operation, stressing and quantifying the contribution of emissions and ink components in the later one.

In summary, the session was very fruitful since it exhibited a remarkably good balance between general aspects and particular case studies and enabled interesting discussions and opinion exchanges among the audience. As a whole, the session provided an overview on the paper and leather sectors useful for future work.

\subsection{Additives used in the plastic sector}

The session was dedicated to additives employed on the plastics sectors. It included two presentations, covering both general aspects and specific case studies.

Dr. Ester v.d.Voet presented the results of a quick scan that has been conducted on plastics and their additives to identify databases that could be used to assess risks and conduct LCAs with relevance for additives. Data about plastics production and consumption were presented. The 
figures are available for the entire world, the continents and for countries, in varying degrees of detail (Table 1). Dr. v.d. Voet highlighted that data on plastics waste are scarce and specific polymers are often not identified. Some data can be found for the EU25 and Norway and Switzerland in the year 2005 .

Table 1. The production, import and export of plastics and articles thereof in the world in 2005 (Plastics Europe, 2007)

\begin{tabular}{|c|c|c|c|c|c|c|c|c|c|c|}
\hline \multirow[t]{2}{*}{ region } & \multirow{2}{*}{$\begin{array}{l}\text { production } \\
\text { plastics }\end{array}$} & \multicolumn{4}{|c|}{ import plastics and articles thereof } & \multicolumn{4}{|c|}{ export plastics and articles thereof } & \multirow{2}{*}{$\begin{array}{l}\text { apparent } \\
\text { consumption }\end{array}$} \\
\hline & & $\begin{array}{l}\text { import } \\
\text { total }\end{array}$ & $\begin{array}{l}\text { import } \\
\text { primary } \\
\text { material }\end{array}$ & $\begin{array}{l}\text { import } \\
\text { waste }\end{array}$ & $\begin{array}{l}\text { import } \\
\text { articles } \\
\text { thereof }\end{array}$ & $\begin{array}{l}\text { export } \\
\text { total }\end{array}$ & $\begin{array}{l}\text { export } \\
\text { primary } \\
\text { material }\end{array}$ & $\begin{array}{l}\text { export } \\
\text { waste }\end{array}$ & $\begin{array}{l}\text { export } \\
\text { articles } \\
\text { thereof }\end{array}$ & \\
\hline EU27 & $5.75 \mathrm{E}+10$ & $9.43 \mathrm{E}+09$ & $5.58 \mathrm{E}+09$ & $2.32 \mathrm{E}+08$ & $3.62 E+09$ & $1.54 \mathrm{E}+10$ & $9.83 \mathrm{E}+09$ & $1.67 \mathrm{E}+09$ & $3.91 \mathrm{E}+09$ & $5.30 \mathrm{E}+10$ \\
\hline NAFTA & $5.29 \mathrm{E}+10$ & $3.86 \mathrm{E}+10$ & $1.31 \mathrm{E}+10$ & $7.27 \mathrm{E}+08$ & $2.47 E+10$ & $2.43 \mathrm{E}+10$ & $1.63 \mathrm{E}+10$ & $1.37 \mathrm{E}+09$ & $6.67 \mathrm{E}+09$ & $6.78 \mathrm{E}+10$ \\
\hline Rest of Asia & $3.80 \mathrm{E}+10$ & $1.68 \mathrm{E}+10$ & $1.34 \mathrm{E}+10$ & $4.02 \mathrm{E}+08$ & $2.99 \mathrm{E}+09$ & $3.21 \mathrm{E}+10$ & $2.49 \mathrm{E}+10$ & $8.37 \mathrm{E}+08$ & $6.33 \mathrm{E}+09$ & $2.32 \mathrm{E}+10$ \\
\hline China & $3.45 \mathrm{E}+10$ & $2.46 \mathrm{E}+10$ & $1.82 \mathrm{E}+10$ & $4.96 \mathrm{E}+09$ & $1.44 \mathrm{E}+09$ & $1.03 \mathrm{E}+10$ & $1.89 \mathrm{E}+09$ & $4.47 \mathrm{E}+07$ & $8.41 \mathrm{E}+09$ & $4.39 \mathrm{E}+10$ \\
\hline $\begin{array}{l}\text { Middle East, } \\
\text { Africa }\end{array}$ & $1.84 \mathrm{E}+10$ & $8.51 \mathrm{E}+09$ & $6.33 E+09$ & $6.28 \mathrm{E}+07$ & $2.12 E+09$ & $9.42 E+09$ & 7.76E+09 & $9.93 E+07$ & $1.56 \mathrm{E}+09$ & $1.75 E+10$ \\
\hline Middle East & & $4.66 E+09$ & $3.49 E+09$ & $4.27 E+07$ & $1.13 E+09$ & $8.37 E+09$ & $7.11 E+09$ & $6.95 E+07$ & $1.19 E+09$ & \\
\hline Africa & & $3.85 E+09$ & $2.84 E+09$ & $2.01 E+07$ & $9.90 E+08$ & $1.05 E+09$ & $6.54 E+08$ & $2.99 E+07$ & $3.69 E+08$ & \\
\hline Japan & $1.27 \mathrm{E}+10$ & $2.94 \mathrm{E}+09$ & $1.47 \mathrm{E}+09$ & $3.08 \mathrm{E}+06$ & $1.47 \mathrm{E}+09$ & $5.89 \mathrm{E}+09$ & $4.10 \mathrm{E}+09$ & $1.06 \mathrm{E}+09$ & $7.29 \mathrm{E}+08$ & $1.08 \mathrm{E}+10$ \\
\hline Latin America & $9.20 \mathrm{E}+09$ & $4.91 \mathrm{E}+09$ & $3.88 \mathrm{E}+09$ & $1.89 \mathrm{E}+07$ & $1.02 \mathrm{E}+09$ & $3.30 \mathrm{E}+09$ & $2.53 \mathrm{E}+09$ & $7.77 \mathrm{E}+07$ & $6.88 \mathrm{E}+08$ & $1.09 \mathrm{E}+10$ \\
\hline CIS & $6.90 E+09$ & $3.86 \mathrm{E}+09$ & $2.36 \mathrm{E}+09$ & $7.63 E+06$ & $1.50 \mathrm{E}+09$ & $1.10 \mathrm{E}+09$ & $8.57 \mathrm{E}+08$ & $2.16 \mathrm{E}+07$ & $2.21 \mathrm{E}+08$ & $9.68 \mathrm{E}+09$ \\
\hline unit & $\mathrm{kg}$ & $\mathrm{kg}$ & $\mathrm{kg}$ & $\mathrm{kg}$ & $\mathrm{kg}$ & $\mathrm{kg}$ & $\mathrm{kg}$ & $\mathrm{kg}$ & $\mathrm{kg}$ & $\mathrm{kg}$ \\
\hline
\end{tabular}

Note: apparent consumption = production plastics + import primary material + import articles thereof - export primary material - export articles thereof

Additives in plastics have different functions, providing the plastic material with the desired characteristics. Within the presentation a number of additives were presented, grouped by their function, together with the polymers in which the additive is used. It was also mentioned that statistical data on the production of additives is hard to find, but market sales analysis can be used as an approximation of consumption. The global manufacturing of plastics shifts to Far East and so does the production of plastic additives. The majority of the plastic additives capacity expansion is carried out in China, Middle East, India, Russia, Eastern Europe and other regions in AsiaPacific. Environmental friendly products such as nonhalogenated flame-retardants, organic heat stabilizers and fiber-reinforced thermoplastics represent some of the potential growth areas for global additives.

Additional to the data research, different LCA options for plastics were presented and several LCA databases were checked. Sometimes it is mentioned that the database includes process data on plastics, however, it is not clear whether these plastic processes refer to aggregated data of separate processes. For the environmental impacts of human toxicity and ecotoxicity there are numerous chemicals for which characterization factors are available, including chemicals that are used as additives in plastics such as heavy metals (zinc, lead, organotins) and phthalates. For some of the additives, the characterization factors for toxicity are not yet available.

Mr. Veit Grundmann offered the second presentation of this session on the problems that might occur during plastic recycling processes (Kamimura and Yamamoto, 2007). Mr. Grundmann explained why plastics are used and how the additives can influence their chemical and physical properties. Since mechanical recycling of plastics (which involves the mechanical recovery of material from waste) is the most common way of plastics recycling, the majority of problems may occur during this step. Feedstock recycling refers to the reuse of plastics as a feedstock in other industrial processes such as reducing agent, fuel or even monomers to make new plastics, but plays only a minor role within the plastic recycling.

\subsection{Additives used in lubricants, textile and electronic products}

This session was devoted to the additives used in three different industries: lubricants, textiles and electronics. Five speakers presented their works related to these sectors.

In first place, Dr. Emilio Benfenati introduced the lubricants, focusing on their main characteristics and impact on the environment. After reviewing the most important additives used in this sector, a final selection was done: perfluorinated compounds (PFOs/PFOA), (pNonylphenoxy) acetic acid (NPAA) and polybrominated diphenyls (PBDEs).

In second place, Dr. Rosa Mari Darbra presented the results of WP5 research on the textile sector (Graedel et. al., 2004). This presentation focused on the potential harm that additives used in the production and manufacture of textiles may have to the environment and human health. A selection of the most representative additives in this sector was presented: flame retardants (brominated compounds), repellent finishers (perfluorocarbon compounds) and antimicrobial finishers (e.g. Triclosan) (OECD, 2004). For these substances, a deep study on their potential risk to the environment and human health was performed (European Commission, 2003), obtaining general risk 


\begin{tabular}{|c|c|}
\hline ENVIRONMENT & HEALTH \\
\hline Risk Quotient $(R Q)=\frac{\text { PEC }_{\text {i }}}{\text { PNEC }_{i}}$ & Margin Of Safety $($ MOS $)=\frac{\text { PTDI }}{\text { Exposure }}$ \\
\hline $\begin{array}{l}\text { PEC: Predicted Environmental Concentration } \\
\text { PNEC: Predicted No Effect Concentration } \\
\text { i: Environmental compartment }\end{array}$ & $\begin{array}{l}\text { PTDI: Provisional Tolerable Daily Intake } \\
\text { Exposure: Dose of exposure estimated }\end{array}$ \\
\hline
\end{tabular}

\section{Figure 3. Expressions to calculate the environmental and health risk}

Continuing with the textile sector, Col. Rakesh Johri gave a lecture on the hazardous waste in the textile dying process in India. In particular, he focused on the chemical sludge produced when treating the effluents and analysed samples from four different locations.

Prof. Do Quang Trung gave a very interesting presentation on electronic waste management and recycling in Vietnam. The increase of this type of waste in Vietnam was highlighted, whereas entire villages are devoted to recycle electronic waste. Nevertheless, the risk for human health and for the environment is very high (increasing concentrations of heavy metals in soil). Prof. Do stressed the need of increasing public awareness and developing more research on e-waste recycling.

Finally, Dr. Mohammed Belhaj introduced the research carried out by WP7 on electronics. Four additives were selected as the most interesting ones in this sector: mercury, lead, triphenyl phosphate (TPP) and polybrominated diphenyls (PBDEs). Information on the health impact of these substances was provided as well as some economic models to assess this impact. The concept of risk perception was introduced to the audience, in order to study the gap with the real risk (Wiedemann, 1996; de Hang, 1996). In conclusion, this session was very useful to identify through the interaction with the audience the most suitable additives in the lubricant, textile and electronic sectors and to be able to continue with RISKCYCLE research.

\subsection{Uncertainty and toxicity in risk assess- ment}

In this session, more specific presentations from a waste and geographical point of view were given, but also presentations that set up the premises for the activities on risk assessment. This completed the overview of the situation of electronic waste, also relatively to a geographical area (India). In addition, the workshop included presentations on the general aspects of risk assessment, also keeping into account uncertainty. Four speakers presented their works related to these sectors.

The first presentation, given by Col. Rakesh Johri, addressed the situation of the electronic waste in India. The problems, which are typical for activities related to waste, are exacerbated by the local critical situation, with an increase of the exposure for people handling the contaminated material. Some social initiatives were introduced and the case study of Delhi presented.

Prof. Susanne Heise, who gave the second presentation in this session, provided a general overview on the transfer of contaminants and the flow related to the waste, with particular attention to the electronic waste. The attention was given to some chemicals associated to this kind of waste, such as mercury, lead, but also organic compounds such as brominated diphenylethers and organophosphorus chemicals, offering opportunities to a closer discussion on specific examples.

The general aspects related to the waste-related contaminants were then addressed, first within the presentation given by Dr. Dominique Gyuonnet. The relevance of uncertainty within the risk assessment procedure was discussed (Liu, 2007; Regan et al., 2004). A particular approach to identify boundaries for a more realistic scenario was presented. This approach, published in the past by the presenter, can be adopted within RISKCYCLE.

Dr. Emilio Benfenati gave the last presentation by addressing an approach to integrate the information relative to toxicity, ecotoxicity and environmental properties. An integrated index has been proposed, ERICA, offering the advantage to produce into a single value the overall evaluation of the toxicity related to a certain waste, on the basis of the contaminants present. Thus, the flux of different wastes could be analysed in terms of toxicity flux.

\section{Conclusions of the workshop in Vi- etnam}

At the end of the workshop, Prof. Nguyen Thi Diem Trang, Prof. Dr. Bernd Bilitewski, and Prof. Dr. Damià Barceló led the session dedicated to final discussions and conclusions.

The exchange of information done in the workshop proved to be very useful for the audience. The advice provided by the advisory board to the scientists attending the workshop was of high relevance for the continuation of the project. The session allowed the identification of the most interesting additives to be studied in different industrial sectors. 
Complying with one of the main objectives of the workshop, different contacts were made between developing and developed countries for further collaboration concerning waste recycling.

One of the main outcomes was the agreement between different experts (scientists, stakeholders, etc.) about the complexity of risk assessment of chemicals in a global approach. This situation involves not only scientific aspects, but also political and economic issues, which further complicates the identification of solutions. Furthermore, there is a lack of details useful to better describe the amount and nature of waste and contaminants. This underlines the need of initiatives like RISKCYCLE.

\section{Publication of all project results}

Meanwhile, the project RISKCYCLE is in its closing stages and results have already been achieved. For each of the considered six fractions a list with five main additives has been compiled. Using these selected additives, exemplary investigations were carried out within the single work packages, such as life cycle assessment of additives in the plastics and paper industries, or the use of different risk assessment methodologies to investigate the effects of using these additives and their behaviour in various recycling processes. The results of these investigations and the first project outcomes are published in the book 'Global Risk-Based Management of Chemical Additives I (Production, Usage and Environmental Occurrence)' (Bilitewski et al., 2012).

Additional results of the second project period will be published at the end of 2012 as part of the book, 'Chemical Additives in Selected Industrial Sectors at a Global Scale II (Risk-based Assessment and Management Strategies)'. All other reports are also available for download on the project homepage (www.wadef.com).

\section{Final RISKCYCLE conference 2012}

The final RISKCYCLE conference "Risk-Based Management of Chemicals and Products in a Circular Economy at a Global Scale" will be held on 8 and 9 May 2012 in Dresden, Germany.

Selected results of investigations and case studies will be introduced and presented in the following categories:

- Flow and emissions of additives - from production to reuse, recycling and waste for the following sectors: textiles, electronics, plastics, leather, paper and lubricants

- Fate and behaviour of chemical additives in recycling products

- Alternative toxicity testing for additives in products to reduce animal test in line with the objectives of the REACH directive
- Risk assessment methodologies and mitigation strategies for human health and environment related to additives

- Importance of additives in life cycle assessment of textiles, electronics, plastics, leather, paper and lubricants

- Bridging research needs with policy in the field of Risk-Based Management of Chemicals and Products.

Conference registration and more information about the venue and accommodation possibilities are available on the conference website: www.faa-tagungen-dresden.de/ en/riskcycle.

\section{Acknowledgements}

The project RISKCYCLE receives funding from the European Community's Seventh Framework Programme under grant agreement $n^{\circ}$ FP7-226552. The organizing team (TUD and HUS) want to thank all the participants, especially the personnel from HUS for their contribution to the workshop.

\section{References}

[1] de Haan G. 1996. Die Kommunikation über ökologische Gesundheitsrisiken. In G. d. Haan, Ed, Ökologie - Gesundheit - Risiko. Perspektiven ökologischer Kommunikation, Akademie Verlag GmbH, Berlin

[2] Graedel T., Howard-Grenville, J. 2005. Chapter 15. Textiles and leathers. In: Graedel T., HowardGrenville, J. (ed.) Greening the industrial facility: Perspectives, approaches and tools. USA: Springer, 2005, 257-269. ISBN-10 0387243062

[3] Hung D.Q., Thiemann W. 2002. Contamination by selected chlorinated pesticides in surface waters in Hanoi, Vietnam. Chemosphere 47:357-367

[4] Kamimura, A. and Yamamoto, S. (2007): An Efficient Method To Depolymerise Polyamide Plastics: A New Use of Ionic Liquids Organic Letters 9(13):2533-2535

[5] Liu, B.D. 2007. Uncertainty Theory, $2^{\text {nd }}$ Ed., Springer-Verlag, Berlin (http://orsc.edu.cn/liu/ut.pdf, retried on 2010-05-03)

[6] Larsen, H.F., Hansen, M.S., Hauschild, M. 2009. Life-cycle assessment of offset printed matter with EDIP97 - how important are emissions of chemicals? J. Clean Prod. 17:115 - 128

[7] Minh N.H., Minh T.B., Kajiwara N., Kunisue T., Iwata H., Viet P.H., Tu N.P.C., Tuyen B.C., Tanabe S. 2006. Contamination by polybrominated diphenyl ethers and persistent organochlorines in catfish and feed from Mekong River Delta, Vietnam. Environ. Toxicol. Chem. 25:2700-2709

[8] OECD. 2004. Series on emission scenario documents. Number 7. Emission scenario document on textile finishing industry. ENV/JM/MONO (2004) 


\section{2. $77 \mathrm{pp}$}

[9] Plastics Europe. 2007. http://www.plasticseurope. co.uk/ (retrieved on 2010-05-03)

[10] Regan, H.M., Ferson, S., Berleant, D. 2004. Equivalence of methods for uncertainty propagation of realvalued random variables. Int. J. Approx. Reasoning 36(1):1-30

[11] Vietpaper, 2007. www.vietpaper.com (retrieved on 2010-05-03)
[12] Wiedemann P. M. 1996. Industrieansiedlungen Risiko, Risikokommunikation und Risikomanagement. In: G. d. Haan (Ed.): Ökologie - Gesundheit Risiko. Perspektiven ökologischer Kommunikation, Akademie Verlag GmbH, Berlin.

[13] Bilitewski, B., Darbra, R.M., Barceló, D. (Ed.) 2012. Global Risk-Based Management of Chemical Additives I (Production, Usage and Environmental Occurrence); The Handbook of Environmental Chemistry, Vol. 18; Springer Verlag, Heidelberg. ISBN: 978-364224875 